\title{
BEBERAPA CATATAN TERHADAP KITAB - KITAB KARYA ULAMA MINANGKABAU PADA PERMULAAN ABAD XX
}

\author{
Pramono \\ Zahir Ahmad
}

\begin{abstract}
The Kitabs (manuscripts and printed) of Minangkabau Scholars in the Early Twentieth Century are an important local sources in reconstructing the multicultural reconstruction of local Islamic. Era of the transmission of ideas and Islamic reformation movement in West Sumatra that began in the early twentieth century has given birth to two kinds of religious groups, namely "Kaum Tua" or "traditionalists" and "Kaum Muda" or "The Modernist" which have polemics each other. Islamic polemic had a positive effect on the proliferation of copying and writing traditions of the manuscript. Many ulama or sheikh from each group write and copy the script to argue with opinions which he said is not true. Therefore, these manuscripts are important and can be a source of authentic Islamic in seeing the dynamics of Islamic conflict and resolution in West Sumatra.
\end{abstract}

Keywords: conflict, Islamic, manuscript, ulama and Minangkabau.

\section{Pendahuluan}

Wacana Islam lokal di Sumatera Barat memiliki corak yang khas, terutama di era transmisi gagasan dan gerakan pembaharuan Islam yang dimulai pada awal abad XX. Dalam konteks itu, lahir dua macam golongan keagamaan, yaitu "Kaum Tua" atau "Kaum Tradisionalis" dan "Kaum Muda" atau "Kaum Modernis"1

1 Pada awalnya istilah "Kaum Muda" dan "Kaum Tua" merujuk pada gerakan Dt. St. Maharaja bersama 11 orang anggotanya dari daerah Darek yang menamakan diri sebagai Kaum Muda untuk melawan penduduk Kota Padang dari kalangan "bangsawan” yang mereka sebut dengan kelompok Kaum Tua pada permulaan abad ke-20 (1905-an). Gerakan ini bertujuan untuk mengajak masyarakat untuk kembali kepada adat Minangkabau yang asli. Gerakan ini sekaligus untuk memurnikan adat Minangkabau yang dari pengaruh adat kebiasaan orang-orang Aceh yang tergabung dalam kelompok bangsawan di Padang. Kedua istilah itu selalu dipopulerkan oleh Dt. St. Maharaja melalui pemberitaan di koran Pelita Kecil miliknya. Dalam perkembangan selanjutnya, ketika terjadi gerakan pembaharuan Islam di Minangkabau yang dimulai ketika sekembalinya H. Abdullah Ahmad dan H. Abdul Karim Amrullah dari Mekah dengan membawa paham pembaharuan, maka kedua istilah itu lebih merujuk pada golongan pembaharu dan golongan tradisional. Baca: B.J.O Schrieke, Pergolakan Agama di Sumatera Barat: Sebuah Sumbangan Bibliografi (Jakarta : Bhatara, 1972), hlm. 43 dan 45. Liohat juga: M. Sanusi Latief, "Gerakan Kaum Tua di Minangkabau", Disertasi (Jakarta : IAIN Syarifhidayatullah, 1988), hlm. 127-133. Keterangan yang berbeda terkait dengan asal-muasal kedua istilah itu disebutkan oleh Imam Maulana Abdul Manaff Amin Al-Khatib, "Risalah Mizan al-Qalb untuk Bahan Peretimbangan Bagi Kaum Muslimin Buat Beramal Ibadah Ke- 
yang saling berpolemik. Dalam perkembangannya, dinamika polemik keislaman tersebut menjadi lebih kompleks. Kaum Tua yang juga penganut tarekat tidak hanya berpolemik dengan Kaum Muda, melainkan pada saat yang sama juga menghadapi pertentangan antarsesama penganut tarekat sendiri. Lebih kompleks lagi, polemik keislaman juga terjadi di dalam tubuh satu penganut tarekat yang sama.

Konflik keislaman seperti itu masih tetap hidup dan berpengaruh dalam masyarakat Minangkabau hingga hari ini. Akan tetapi, justru polemik keislaman pada masanya itu berdampak positif terhadap suburnya tradisi penyalinan dan penulisan naskah. Banyak ulama atau Syekh dari masing-masing golongan menulis dan menyalin naskah ${ }^{2}$ untuk mendebat pendapat yang menurutnya tidak benar atau tidak berdasar.

Dengan demikian, di dalam naskah-naskah tersebut terkandung banyak informasi berharga yang dapat dimanfaatkan untuk mengetahui corak dan dinamika konflik keislaman di Sumatera Barat. Sayangnya, penelitian tentang polemik tersebut, terutama melalui naskah-naskah keislaman Minangkabau itu belum terekam dengan baik. Dengan demikian, tulisan ini dimasudkan untuk menambah khasanah literatur terkait tema tersebut.

\section{Kitab Karya Ulama Minangkabau}

Dalam konteks pedebatan dan polemik keislaman di Minangkabau banyak ulama yang mengajar di suatu surau, menyalin dan menulis naskah. Naskah-naskah yang disalin dan ditulis tersebut dimaksudkan untuk menyebarkan pengajian dan mendebat ataupun mengkritik pendapat orang lain serta untuk mengkritik keadaan sosial. Hal ini memberikan gambaran bahwa surau bukan sekedar tempat belajar membaca Alquran atau belajar adab, melainkan surau merupakan pusat kecendekiaan, center for excelent. Hal ini sekaligus kesan bahwa apa yang dilakukan para ulama tarekat, dalam mempertahankan paham keagamaannya, adalah bagian dari kebiasaan berdebat yang dikembangkan di kalangan ulama, sebuah kegiatan intelektual Islam di Minangkabau. Menulis kitab merupakan salah satu alternatif untuk menolak paham yang dianggap tidak benar.

Surau menjadi institusi penting dalam proses transmisi berbagai pengetahuan Islam. Di surau itulah para ulama dari masing-masing golongan tarekat membangun jaringan guru-murid sehingga tercipta saling-silang hubungan keilmuan yang sangat kompleks. Seiring dengan persebaran paham keagamaan Islam di surausurau tersebut, tradisi penulisan dan penyalinan naskah pun tumbuh dengan subur. Para syaikh, ulama, buya, atau ungku yang mengajar di suatu surau, menyalin dan

pada Allah", Manuskrip ditulis 1989. Dalam manuskrip ini disebutkan bahwa istilah "Kaum Muda" dan

"Kaum Tua" muncul setelah pertemuan di rumah Haji Jamil di Kampung Pondok Padang antara dua kelompok, yakni kelompok ulama tua di kota Padang, yaitu Syaikh Khatib Muhammad 'Ali al-Fadani, Syaikh Muhammad Dalial (Tuanku Syaikh Bayang), Tuanku Syaikh Khatib Saidina, Syaikh Muhammad Thaib Seberang Padang dan Tuanku Imam Masjid Gantiang Padang dengan kelompok ulamamuda yang terdiri dari Haji Abaz Daud Balingka (Inyik Balingka), Haji Abdullah Ahmad Padang Panjang dan Haji Abdul Karim Amrullah Maninjau yang menudian dimasyhurkan orang dengan Inyik Rasul. Pertemuan ini mendebatkan persoalan tarekat dan rabithah.

2 Naskah dalam tulisan ini merujuk pada kumpulan tulisan baik tulisan Arab, Arab-Melayu atau Jawi, baik tulis tangan atau cetak yang masih dikoleksi oleh masyarakat maupun perpustakaan yang mengandung teks polemik keislaman Minangkabau mulai awal abad ke-20 sampai hari ini. 
menulis naskah. Di samping itu, para ulama itu juga membawa berbagai kitab sebagai buah tangan ketika "pulang kampung" dari tempat belajarnya. Kitab-kitab tersebut selanjutnya digunakan sebagai bahan bacaan atau sumber pengetahuan yang penting untuk pengajaran di surau-surau.

Pada perkembangan berikutnya, baik ulama atau guru di sebuah surau maupun murid-muridnya banyak melakukan penyalinan naskah. Penyalinan naskah yang dilakukan ulama biasanya dilakukan atas permintaan murid atau orang lain. Salah satu contoh dari praktik penyalinan naskah seperti ini adalah penyalinan naskah yang dilakukan oleh Syaikh Abdul Madjid (w. 1984), seorang ulama tarekat Naqsabandiyah di Lubuk Landur, Pasaman. Syaikh Abdul Madjid menyalin empat naskah, yakni Anwâr Daqâiq, Jawâmi'ul Amal, Dairatul Wujud, dan Bayan Tajjalli. Tiga naskah pertama merupakan salinan dari karya Syamsuddin bin Abdullah Sumatrani dan satu naskah yang terakhir merupakan salinan dari karya Syaikh Abdurrauf Singkel. Penyalinan naskah tersebut dilakukan oleh Syaikh Abdul Madjid dalam rangka memenuhi permintaan yang datang dari murid-murid dan masyarakat yang dibimbingnya (Murkilim, 2006: 20). Hal ini dapat dilihat pada bagian awal salinan naskah Anwâr Daqâiq sebagai berikut.

\begin{abstract}
“Telah tergerak hati hamba hendak mengarangkan satu risalah yang amat kecil lagi sedikit perkataan dan bicaranya, yaitu menerangkan ilmu dan amal atas jalan ilmu pengetahuan bagi ilmu Tarekat Naqsyabandiyah al 'aliyah. Sebab banyak sekali kaum-kaum dan sanak saudara hamba berkehendak atau meminta kepada hamba agar menerbitkan sebuah karangan kitab, untuk menerangkan bagaimana mulanya itu ilmu dan bagaimana jalan mengamalkannya. Sepatutnya hamba ini belum lagi ahli bagi pengarang akan yang demikian itu, maka hamba mintak tolong kepada Allah SWT. yang akan menyempurnakan pintak dan tuntutannya kaum hamba itu. Tiada daya dan upaya hamba akan menyempurnakan akan yang demikian melainkan dengan tolongan dari pada Allah Ta'ala jua, wa mầ taufíqi illa billâhi al 'aliyy al 'adhîmi" (Madjid, 1961: 2).
\end{abstract}

Adapun penyalinan yang dilakukan oleh murid-murid di suatu surau biasanya dimaksudkan untuk memiliki isi naskah. Salinan naskah tersebut nantinya akan dibawa pulang ke kampung halaman setelah ia "menamatkan pendidikan" di surau tempatnya belajar. Beberapa contoh dari penyalinan naskah seperti ini misalnya yang dilakukan oleh Imam Maulana Abdul Manaf Amin Al-Khatib ${ }^{3}$ (w. 2006), Munas Katik Marajo 4 (65 tahun) dan Ismail Rahmat (w. 1998) ${ }^{5}$. Proses penyalinan naskah-naskah milik sang guru tersebut biasanya dilakukan di mihrab sebuah surau.

3 Imam Maulana Abdul Manaf Amin Al-Khatib (w. 2006) adalah ulama Tarekat Syattariyah di Batang Kabung, Koto Tangah, Padang. Semasa belajar di Surau Ampalu Tinggi, Padang Pariaman, belaiu menyalin naskah Tanbih Almasyi milih gurunya, Syaikh Ibrahim. Selain itu, beliau juga menyalin beberapa naskah milik Syaikh Paseban sewaktu belajar di Surau Paseban, Koto Tangah, Padang.

4 Munas Katik Marajo (65 tahun) adalah buya tarekat Samaniyah di di Jorong Lubuk Jaya Kanagarian Koto Baru, Kecamatan Sungai, Kabupaten Solok Selatan. Beliau menyalin naskah di Talang Bungo, Alahan Panjang, Solok dari naskah yang dimiliki gurunya yang bernama Syaikh Muhamad Husein Talang Bungo.

5 Ismail Rahmat (w. 1998) atau dikenal dengan nama Ongga adalah guru Tarekat Naqsabandiyah di di Surau Darul Mualimin (yang sekarang bernama mushalah Darul Mualimin), Lubuk Kilangan, Padang. Sewaktu Ongga belajar dengan Syaikh Muda Wali (Tengku Aceh) di Aceh, ia menyalin beberapa naskah milik gurunya. 
Selain kegiatan penyalinan naskah di atas, banyak juga guru-guru surau yang menulis naskah. Naskah yang ditulis tidak hanya mengandung teks keislaman, tetapi juga teks adat, sastera, sosial-budaya dan perobatan. Menariknya, penulisan naskah di Sumatera Barat masih berlangsung hingga tahun 2000-an dan bahkan sampai sekarang. Dalam konteks ini dikenal beberapa penulis naskah di Sumatera Barat, seperti Syaikh H. Abdul Salam $\operatorname{Imam}^{6}$ (w. 2000), Imam Maulana Abdul Manaf Amin al-Khatib ${ }^{7}$ (w. 2006), Janius Ahmad Datuk Mali Puti Alam (w. 2008), Munas Katik Marajo ${ }^{9}$ (65 tahun), Abdul Muas Gelar Tantua Rajo Sutan ${ }^{10}$ (71 tahun) dan lain-lain.

Perkembangan dunia kepenulisan di kalangan ulama Minangkabau tidak hanya sebatas pada naskah salinan tangan. Untuk memperluas ajaran dan paham yang diyakini, banyak ulama juga menerbitkan karyanya. Pada masa ini muncul banyak penerbitan di Sumatera Barat. Dunia kepengarangan di kalangan ulama semakin ramai karena semangat polemik keislaman tempatan.

Dalam konteks polemik keislaman tersebut, suasananya menjadi lebih kompleks karena Kaum Tua yang juga penganut tarekat tidak hanya harus berhadapan dengan Kaum Modernis, melainkan pada saat yang sama juga menghadapi pertentangan antarsesama kelompok Islam golongan penganut tarekat sendiri. Lebih kompleks lagi, polemik keislaman itu juga terjadi di dalam tubuh penganut tarekat yang sama ${ }^{11}$. Hal ini misalnya polemik keislaman yang terjadi antar sesama penganut tarekat Syattariyah maupun tarekat Naqsabandiyah.

Kesan polemik keislaman di atas masih dirasakan dan berpengaruh dalam masyarakat Minangkabau di Sumatera Barat hingga saat ini. Akan tetapi, justeru polemik keislaman itu berdampak positif terhadap suburnya tradisi kepenulisan di kalangan ulama-ulama tempatan. Banyak ulama dari masing-masing golongan menulis untuk mendebat pendapat yang menurutnya tidak benar. Karya-karya

6 H. Abdul Salam Imam (w. 2000) adalah ulama tarekat Syattariyah pendiri Pesantren Tarbiyah Islamiyah yang terletak di Pulai, Kecamatan Sitiung, Kabupaten Dharmasraya. Beliau menulis delapan naskah yang berkaitan dengan tarekat Syattariyah dan syair-syair Islam. Naskah-naskah tersebut saat ini disimpan oleh istrinya yang bernama Hj. Syamsidar (58 tahun). Informasi terkait dengan deskripsi naskah dapat dibaca dalam Yusri Akhimuddin dkk., "Penelusuran dan Katalogisasi Naskah-naskah Koleksi Pribadi di Kabupaten Dharmasraya" (Padang : Balai Bahasa Padang, 2009).

7 Imam Maulana Abdul Manaf Amin Al-Khatib (w. 2006) selain menyalin naskah juga menulis belasan naskah tentang sejarah dan ajaran tarekat syattariyah. Lebih jauh lihat Oman Fathurahman, "Tarekat Syattariyah di Dunia Melayu-Indonesia: Kajian Atas Dinamika dan Perkembangannya Melalui Naskah-Naskah di Sumatera Barat" (Depok : Pascasarjana UI, 2003); lihat juga Pramono, "Tradisi Penulisan dan Penyalinan Naskah-Naskah Islam Minangkabau: Kajian Atas Imam Maulana Abdul Manaf Amin Al-Khatib dan Karya-Karyanya" (Padang : Lembaga Penelitian Unand, 2006).

8 Janius Ahmad Datuk Mali Puti Alam (2008) menulis naskah tentang ajaran tarekat Naqsabandiyah dan adat Minangkabau. Semasa hidupnya beliau dan menjadi guru tarekat Naqsabandiyah di Surau Suluk, Nagari Sarilamak, Kecamatan Harau, Kabupaten Limapuluh Kota. Gambaran tentang karya-karya beliau dapat dilihat lebih jauh dalam Pramono, "Tarekat Naqsabandiyah di Kabupaten Lima Puluh Kota: Studi Atas Dinamikanya Melalui Teks dan Konteks Naskah-naskah Karya Janius Ahmad Datuk Mali Puti Alam" (Padang : Lembaga Penelitian Unand, 2009).

9 Munas Katik Marajo (65 tahun) tinggal di Jorong Lubuk Jaya Kanagarian Koto Baru, Kecamatan Sungai, Kabupaten Solok Selatan. Selian menyalin naskah yang berkenaan dengan tarekat Saman, beliau juga sampai saat sekarang menulis beberapa naskah yang berisi syair dan obat-obatan serta peramalan.

10 Abdul Muas Gelar Tantua Rajo Sutan (71 tahun) tinggal di Jorong Pasar, Kanagarian Bidar Alam, Kecamatan Sangir Jujuhan, Kabupaten Solok Selatan. Selain menulis teks keislaman, beliau juga menulis naskah yang berisi tentang adat Minangkabau, perobatan, mantra dan peramalan.

11 Polemik antara ulama penganut Tarekat Syattariyah dengan Naqsabandiyah salah satunya tentang penentuan awal Ramadhan. Polemik yang terjadi antarsesama penganut tarekat Syattariyah tentang tempat ziarah kubur Syaikh Abdurrauf Singkel, sebagain mempercayai di Singkil dan sebagiannya di Kuala, Aceh. 
mereka wujud dalam bentuk naskah salinan tangan dan salinan cetakan dengan menggunakan aksara Jawi dan Arab.

Dinamika penulisan dan penerbitan karya ulama Minangkabau marak dilakukan pada awal abad ke-20. Dari golongan Kaum Tua, ada beberapa ulama yang berkarya seperti: (a) Syaikh Muhammad Sa'ad Mungka sebanyak 3 karya; (b) Syaikh Bayang Muhammad Dalil sebanyak 5 karya; (c) Syaikh Khatib Muhammad Ali Al-Fadani sebanyak 30 karya; (d) Syaikh Sulaiman Ar-Rasuly 22 karya; (e) Syaikh Muhammad Jamil Djaho 3 karya; (f) Syaikh Muda Abdul Qadim sebanyak 2 karya; (g) Haji Abu Bakar Ali Maninjau sebanyak 1 karya; (h) Haji Mansur Datuk Nagari Basa sebanyak 9 karya; (i) Haji Muhammad Zain Simabur sebanyak 5 karya; (j) Haji Sirajuddin Abas sebanyak 16 karya; (k) Hajjah Syamsiyah Abbas sebanyak 1 karya; (l) Haji Yunus Yahya Magek sebanyak 2 karya; (m) Haji Jalaluddin sebanyak 42 karya; dan (n) Haji Imam Maulana Abdul Manaf Amin Al-Khatib sebanyak 22 karya $^{12}$.

Adapun di kalangan ulama Kaum Muda yang berkarya seperti: (a) Syaikh Abdul Karim Amrullah sebanyak 29 karya; (b) Syaikh Abdullah Ahmad sebanyak 5 karya; (c) Syaikh Muhammad Thaib Umar sebanyak 3 karya; (d) Syaikh Muhammad Jamil Jambek sebanyak 5 karya; (e) Syaikh Ibrahim Musa Parabek sebanyak 4 karya; (f) Syaikh Abbas Abdullah Padang Japang sebanyak 1 karya; (g) Ustaz Zainuddin Labay sebanyak 24 karya; (h) Haji Jalaluddin Thaib sebanyak 2 karya; (i) Engku Mudo Abdul Hamid Hakim sebanyak 5 karya; (j) Prof. Dr. Mahmud Yunus sebanyak 64 karya; (k) Prof. Dr. H. Mukhtar Yahya sebanyak 34 karya; (k) Prof. H. Ilyas Muhammad Ali sebanyak 5 karya; (l) Prof. H. Bustami Abdul Gani sebanyak 5 karya; (m) Prof. Dr. Hamka sebanyak 115 karya; (n) Ustaz H. Karim Bakri sebanyak 5 karya; (o) Ustaz Mawardi Muhammad sebanyak 9 karya; (p) Ustaz Zainal Abidin Ahmad sebanyak 8 karya; (q) Ustaz Nashruddin Thaha sebanyak 10 karya; (r) Ustaz Abdur Rahim Al-Munafiy; (s) AR. Sutan Mansur sebanyak 2 karya; dan Ustaz A. Malik Ahmad sebanyak 2 karya ${ }^{13}$.

Menariknya, dalam konteks polemik keislaman tempatan, beberapa ulama menulis dalam bentuk sastera, khususnya dalam genre syair. Tema-tema polemik keislaman yang wujud dalam syair-syair tersebut meliputi polemik permasalahan khilafiah dan tarekat (tasawuf). Ulama-ulama yang menulis syair tersebut yaitu Syaikh Bayang Muhammad Dalil (1984-1923), Syaikh Khatib Ali Al-Fadani (18631936), Syaikh Muhammad Thaib Umar Sungayang (1974-1920), Syaikh Haji Abdul Karim Amrullah (1879-1949), Syaikh Sulaiman Ar-Rasuly (1871-1970) dan Syaikh Sidi Jamadi serta beberapa ulama lainnya.

Sejauh ini, syair-syair karya ulama itu ditemui dalam salinan tangan maupun salinan cetakan dengan aksara Jawi. Syair-syair tersebut ada kalanya wujud dalam satu karya utuh dan ada pula dalam bentuk fragmen dalam sebuah karya lain yang

12 Apria Putra dan Chairullah Ahmad, Bibliografi Karya Ulama Minangkabau Awal Abad XX, Dinamika Intelektual Kaum Tua dan Muda, (Padang : Kerja sama Komunitas Suluh dengan Indonesian Herritage Centre, 2011), hlm. 110-149. Baca juga M. Sanusi Latief, op. cit., hlm. 647-656 dan B.J.O. Scrieke, Pergolakan Agama di Sumatera Barat Sebuah Sumbangan Bibliogrfafi (penerjemah: Soegarda Poerbakawatja), (Jakarta : Bhratara, 13 Ibid. 1973). 
bukan karya sastera. Untuk jenis ini, syair biasanya terdapat dalam pembukaan atau penutup sebuah karya yang bukan karya sastera. Selain itu, ada pula syair yang ditemui dalam sebuah majalah, yakni Majalah al-Munir (1912) dan al-Mizan $(1916)^{14}$.

Dari pembacaan awal terhadap beberapa syair polemik di atas, pengkaji menemui beberapa hal yang unik, misalnya dalam syair yang bertajuk Tasmaratul Ihsan fi Wiladah Saidil Insan (Buah yang Baik di dalam Kelahiran Penghulu Sekalian Manusia) karya Syaikh Sulaiman Ar-Rasuly. Walaupun syair ini secara keseluruhan berkisah tentang kelahiran hingga wafatnya Nabi Muhammad, tetapi sesungguhnya isinya merupakan apologetik tentang "berdiri maulid"15. Dalam beberapa bait syairnya diungkapkan tentang pembelaannya terhadap tudingan Kaum Muda yang mengganggap "berdiri maulid" itu bid'ah hukumnya. Hal ini dapat dilihat dalam kutipan bait syair berikut ini.

\section{Kelebihan Maulud ${ }^{16}$}

18

Kata junjungan lekaslah raba / siapa kasih kepada hamba / membesarkan aku lekasnya tiba / aku kepadanya sangatlah hiba

19

Dalam surga kami bersama / dalam nikmat bulan pertama / kekal di situ selamalama / berlezat-lezat makan delima

20

Sebagai lagi Nabi berkata / membesarkan Maulud siapa kita / Nabi menolong di padang rata / waktu kiamat dilihat nyata

21

(3) Mehabiskan ${ }^{17}$ belanja siapa orang / ke belanja Maulud gunanya terang / meski setali atau terkurang / sama pahalanya jo belanja perang

22

Segadang bukit kita belanjakan / daripada emas kita keluarkan / sama pahalanya Nabi khabarkan / dengan setali kita gunakan

14 Majalah al-Munir dan al-Mizan masih bertuliskan aksara Jawi. Kedua majalah tersebut kelihatannya dijiwai oleh majalah Al-Manar yang popular di Mesir pada waktu itu. Dengan adanya publikasi itu tokoh ulama yang ada di madrasah yang menerbitkan majalah itu dan dimadrasah sekitarnya diketahui oleh orang banyak dan tersebar di Minangkabau, yang menyebabkan berdatangannya murid-murid dari luar daerah untuk belajar di madrasah-madrasah yang ada di wilayah Minangkabau. Pada waktu bersamaan ketokohan ulama semakin menonjol dengan tampilnya ulama itu sebagai tokoh politik yang membimbing umat Islam dalam menghadapi penjajahan Belanda.

15 Di kalangan Kaum Tua, perayaan Maulid Nabi Muhammad dilakukan dengan berkumpul di surau dan membaca kisah tentang Nabi Muhammad, baik dalam bentuk syair maupun prosa yang dipimpin oleh seseorang. Pada saat bacaan mereka sudah memasuki kisah Nabi Muhammad dilahirkan, maka mereka sama-sama berdiri. Tujuannya adalah untuk menghormati Nabi Muhammad dan ini dianggap sunnah. Oleh ulama dari golongan Kaum Muda, praktek ini dianggap bid'ah.

16 Syaikh Sulaiman Ar-Rasuly, Tasmaratul Ihsan fi Wiladah Saidil Insan, (Bukittinggi : Direkrij Agam, 1923), hlm. 2-5.

17 Dieja m-h-a-b-s-k-n, iaitu menghabiskan. 
23

Berkata Abu Bakar sahabat pilihan / mengeluarkan uang siapa kasihan / ke belanja Maulud tidak berlebihan / jadi taulannya akhir kesudahan

24

Berkata Umar sahabat jauhari / pemberian Allah Khāliqu'l-bāri / mehidupkan ${ }^{18}$ Islam pahala diberi / membesarkan Maulud siapa diri

25

Berkata lagi Saidina Usman / membesarkan maulud siapa teman / mengeluarkan wang dari genggaman / serta kasih lagi pun iman

26

Pahalanya sama dengan berperang / hadir di Badar bersama orang / pahalanya merekat tidaklah kurang / khabarnya nyata sangatlah terang

27

Berkata Ali sahabat yang mulia / membesarkan Maulud siapa manusia / tidaklah keluar dari dunia / melainkan iman jadi bahagia

28

Imam Syafi'i pula berkata / membuat kenduri siapa kita / memanggil saudara umum dan rata / sedia makanan kasih serta

29

Dibangkit Allah hari kiamat / serta orang shaleh sekalian umat / orang mati syahid sejimat-jimat / kekal di surga dalam nikmat

30

Suri Sakti berkata lagi / ke tempat Maulud siapa pergi / siang dan malam ataupun pagi / seolahnya masuk surga yang tinggi

31

Wahai saudara gadang kecilnya / membesarkan Maulud banyak macamnya / semuanya baik gadang pahalanya / asalpun jangan melampau watasnya ${ }^{19}$

32

Sekalian fi'il atau perkataan / yang jaya tanda atas kesukaan / zahirnya Nabi dalam bacaan / semuanya dipuji tidak kecelaan

33

(4) Seperti beralat atau kenduri / mehiasi rumah tempat sendiri / menjamu orang dalam nagari / semuanya baik pahala diberi

34

Atau membaca cerita zahirnya / mendengar saja gadang pahalanya / mengeluarkan uang akan belanjanya / semuanya membesarkan surga balasnya

18 Dieja m-h-y-d-w-p-k-n, menghidupkan.

19 Dieja w-a-t-s-ny, batasnya. 
35

Zahirnya Nabi dibaca orang / kita berdiri berhati girang / kasih dan suka dihati terang / pahalanya besar tidaklah kurang

36

Berdiri Maulud bida'ah hasanah / masuk kepada umumnya sunnah [2] / amalan ulama Mekah Madinah / memunkari dia jadi fatanah

37

Berdiri Maulud tanda hormat / siapa membuat segala umat / dapat pahala hari kiamat / masuk surga dapat nikmat

38

Berdiri ini kita khabarkan / masuk takzim ulama katakan / dalil pun tidak pengeluarkan / kalaunya ada hendak datangkan

39

Taulan sahabat sekaliannya / cerita Maulud banyak macamnya / Arab Melayu atau lainnya / nasyīr dan syair ada keduanya

40

Ada belagu ada nan tidak / memukul rebana kabau cubadak / kulit palut rotan penyadak / semuanya harus boleh berkehendak

41

Tetapi membaca hendak baikkan / huruf dan baris hendak betulkan / panjang pendeknya hendak peliharakan / lagunya saja jangan diharapkan

42

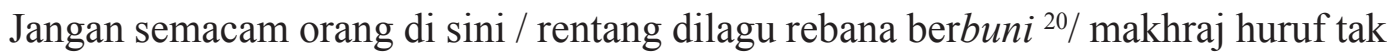
dijalani / akhirnya syurga tak dibauni ${ }^{21}$

43

Setengah bertanda yang elok suara / pandai melagu dalam bicara / lebih-melebihi dengan saudara / akhirnya khusmat jadi perkara

44

Maulud Nabi kalau begitu / nyata ditegah haramnya tentu / jangan dibuat semacam itu / elok berhenti kita di situ

45

(5) Bahasa Arab kalau tak dapat / membaca dia banyak terlompat / bahasa Melayu bacalah cepat / supaya dosa jangan terlipat

46

Bahasa Melayu murah membacanya / tasydīd dan idghām tidak keduanya / jarang

20 Dieja b-r-b-w-n-y, berbunyi.

21 Dieja d-b-w-n-y, dibaumi yang dimaksudkan dengan 'dibau' atau 'dicium'. 
tersalah kita padanya / salah sedikit tidak mudaratnya

47

Bahasa Arab kalau tersalah / makna bertukar betul tidaklah / kita membaca payah dan lelah / akhirnya dosa diberi Allah

48

Wahai saudara taulan ikhwān̄ / dengarlah maksud mengarang ini / menceritakan zahir rasul rabbānī / anak Abdullah bangsa 'adnānī

49

Cerita $Q a$ 'ab kita khabarkan / ke bahasa Melayu kita pindahkan / kurang lebihnya hendak maafkan / kepada Allah tolong doakan

50

Tatkala belum suatu apa / langit dan bumi belum berjumpa / sekalian makhluk semuanya hampa / sekalian tubuh jantung dan limpa

Syair-syair yang dikarang oleh ulama golongan Kaum Tua berisi apologetik (pembelaan) terhadap serangan ulama-ulama Kaum Muda. Sebaliknya, syairsyair yang dikarang oleh ulama Kaum Muda bersifat satira (ejekan). Berikut ini dikutipkan beberapa bait syair ejekan $\mathrm{Haka}^{22}$ (Kaum Muda) yang ditujukan kepada Kaum Tua.

13

Demikianlah hukum pada dirinya / akan dinyatakan adab tertibnya / demikian syarat mengerjakannya / supaya dapat kita pahalanya

14

Aku terangkan sekedar yang dapat / sepanjang syarak bukannya adat / pihak kepada sepenggal alat / orang yang meharap dapat syafaat

15

Wahai saudara kakak dan adi / jikalau maksud hendak khenduri / memanggil pegawai pandai berzanji / atau rebana berdikir tinggi

16

Janganlah Tuan berpayah-payah / kumari berhutang menggadaikan sawah / kebelanja beralat akan sedekah/ asa lai terpuji biarpun susah

17

Di dalam kitab sangatlah terang / seperti itu sangat terlarang / berbuat sunah hanyalah lapang / bukan tersuruh Tuan berhutang

18

Kok ada berlebih nafkah diri / nafkah anak serta bini / hutang yang wajib sudah

22 H. Abdul Karim Amrullah, Irshad al-awam pada menyatakan Maulud Nabi alaihi salam, (Padangpanjang: tanpa penerbit, 1914), hlm. 3 
dibayari / baharullah sunah buat kenduri

19

Jikalau lai seperti itu / boleh syafaat beribu-ribu / asa jan dibuat karena malu / karena nak masyhur hawak si aku

20

Sedekah makanan ataupun uang / karena Allah hendaklah pandang / supaya dapat pahalanya gadang / tidak percuma membuang uang

Dalam konteks dinamika Islam lokal, syair-syair karya ulama-ulama Minangkabau yang mengandung persoalan polemik keislaman merupakan bahan yang penting. Dengan warna bahasa dan estetika tempatan, ulama-ulama tersebut telah menyemarakkan dinamika Islam lokal. Di samping itu, ulama-ulama yang mengambil bagian dalam polemik keislaman telah menunjukkan kebolehan mereka dalam dunia kepangarangan, tradisi bersastra. Syair-syair polemik itu juga menjadi salah satu bentuk kearifan lokal tentang gambaran tradisi intelektual di kalangan ulama yang saling berbeda paham keislaman. Mereka telah mengajarkan tentang bagaimana menghadapi perbedaan faham keislaman dengan tidak menggunakan kekerasan.

Akan tetapi, sayangnya syair-syair karya ulama-ulama Minangkabau tidak mudah ditemukan. Oleh karena itu, boleh jadi ini menjadi salah satu faktor yang menyebabkan kurangnya pengkajian terhadap karya-karya tersebut. Penyebab lainnya dimungkinkan juga karena syair-syair tersebut masih ditulis dengan aksara Jawi, sehingga lebih rumit dan memakan banyak masa untuk mengkajinya. Hal ini berbeda dengan karya-karya Hamka yang juga ulama Minangkabau. Karyakarya Hamka banyak mendapat perhatian para peneliti karena ada anggapan bahwa karya-karya Hamka dianggap narasi besar, sedangkan karya selain Hamka dianggap narasi kecil. Selain itu, karya-karya Hamka dianggap lebih baru (moden) dan mudah ditemukan di perpustakaan.

Penyebab lainnya, seperti yang dikatakan Suryadi (2004 : 2), bahwa ada kecenderungan pengkaji, baik para sarjana Barat maupun Timur, lebih menyenangi teks-teks sastera yang panjang atau prosa sejarah. Adapun syair-syair Islam yang pendek kurang mendapat perhatian. Padahal syair-syair yang pendek dan tentang Islam, seperti syair-syair polemik karya ulama-ulama Minangkabau, tidak kalah penting dibandingkan dengan teks-teks yang panjang. Melalui syair-syair tersebut dapat menjelaskan tradisi sastera dan keagamaan di kalangan ulama-ulama Minangkabau. Oleh karenanya, tujuan penyelidikan ini salah satunya adalah untuk mengisi kekurangan kajian itu.

\section{Penutup}

Banyaknya kitab karya ulama-ulama Minangkabau adalah bukti bagaimana tradisi berdebat dimiliki oleh ulama-ulama di Sumatera Barat. Menulis naskah adalah alternatif untuk melawan pendapat orang lain yang dianggap tidak 
berdasar dan tidak benar. Dalam konteks polemik itu juga telah memperlihatkan tingkat kedalaman penguasaan pengetahuan agama yang dimiliki oleh para ulama Minangkabau pada masa itu.

Oleh karena itu, melalui naskah-naskah keislaman Minangkabau dapat diungkap untuk memberikan konstribusi penting dalam pengungkapan dan rekonstruksi sejarah Islam lokal Minangkabau. Dari naskah-naskah tersebut tidak hanya dapat merekonstruksi sejarah dan wacana lokal Islam Minangkabau, tetapi juga dapat mengungkapkan ekspresi keagamaan masyarakat yang sangat beragam.

\section{Daftar Pustaka}

Akhimuddin, Yusri, dkk., 2009. "Penelusuran dan Katalogisasi Naskah-naskah Koleksi Pribadi di Kabupaten Dharmasraya". Laporan Penelitian. Padang : Balai Bahasa Padang.

Amrullah, H. Abdul Karim. 1994. Irshad al-awam pada menyatakan Maulud Nabi alaihi salam. Padangpanjang: tanpa penerbit.

Ar-Rasuly, Syaikh Sulaiman. 1923. Tasmaratul Ihsan fi Wiladah Saidil Insan. Bukittinggi : Direkrij Agam.

Fathurahman, Oman. 2003. “Tarekat Syattariyah di Dunia Melayu-Indonesia: Kajian Atas Dinamika dan Perkembangannya Melalui Naskah-Naskah di Sumatera Barat". Disertasi. Depok : Pascasarjana UI.

Latief, M. Sanusi. 1988. "Gerakan Kaum Tua di Minangkabau”, Disertasi. Jakarta : IAIN Syarifhidayatullah.

Pramono. 2006. "Tradisi Penulisan dan Penyalinan Naskah-Naskah Islam Minangkabau: Kajian Atas Imam Maulana Abdul Manaf Amin Al-Khatib dan Karya-Karyanya". Laporan Penelitian. Padang : Lembaga Penelitian Unand.

------. 2009. “Tarekat Naqsabandiyah di Kabupaten Lima Puluh Kota: Studi Atas Dinamikanya Melalui Teks dan Konteks Naskah-naskah Karya Janius Ahmad Datuk Mali Puti Alam". Laporan Penelitian. Padang : Lembaga Penelitian Unand.

Putera, Apria \& Chairullah Ahmad. 2011. Bibliografi Karya Ulama Minangkabau Awal Abad XX, Dinamika Intelektual Kaum Tua dan Muda. Padang : Kerja sama Komunitas Suluh dengan Indonesian Heritage Centre.

Schrieke, B.J.O. 1972. Pergolakan Agama di Sumatera Barat: Sebuah Sumbangan Bibliografi. Jakarta : Bhatara.

Suryadi, 2004. Syair Sunur: Teks dan Konteks Otobiografi Seorang Ulama Minangkabau Abad Ke-19. Padang : Citra Budaya. 
